\title{
Relation between Citric Acid Production by Solid-State Fermentation from Cassava Bagasse and Respiration of Aspergillus niger LPB 21 in Semi-Pilot Scale
}

\author{
Flávera Camargo Prado, Luciana Porto de Souza Vandenberghe and Carlos Ricardo \\ Soccol* \\ Departamento de Engenharia Química; Universidade Federal do Paraná; Centro Politécnico; 81531-970; Curitiba - \\ PR - Brasil
}

\begin{abstract}
The aim of this work was to study the relation between citric acid production and respiration of Aspergillus niger LPB 21 in solid-state fermentation of cassava bagasse. The experiments were carried out in horizontal drum bioreactor coupled with a gas chromatography system. Fermentation was conduced for 144 h with initial substrate moisture of $60 \%$ using heat-treated cassava bagasse as sole carbon source. The exhausted air from the bioreactor was analyzed for the monitoring of $\mathrm{CO}_{2}$ produced and $\mathrm{O}_{2}$ consumed in order to estimate the biomass biosynthesis by

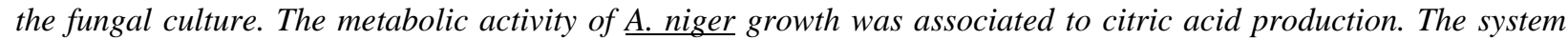
using FERSOL software determined $4.372 \mathrm{~g}$ of biomass $/ \mathrm{g}$ of consumed $\mathrm{O}_{2}$. Estimated and analytically determined biomass values followed the same pattern showing that the applied mathematical model was adapted.
\end{abstract}

Key words: Citric acid, solid-state fermentation, cassava bagasse, horizontal drum bioreactor, fungus respiration

\section{INTRODUCTION}

Among the organic acids industrially produced, citric acid is the most important in quantitative terms with an estimated annual production of about 1000,000 tons (Soccol et al., 2003). The annual growth of its demand/consumption rate is around 3.5 -4.0\% (Pandey et al., 2001; Vandenberghe et al., 2000a). The food industry consumes about $70 \%$ of total citric acid produced and pharmaceutical industries consume about $12 \%$, and the remaining $18 \%$ are consumed by other industries (Soccol et al., 2003; Pandey et al., 2001).

\begin{abstract}
Almost entire quantity of citric acid is obtained through submerged fermentation of starch or sucrose based media, using the filamentous fungus Aspergillus niger (Vandenberghe et al., 2000b). Solid-state fermentation (SSF) has been an alternative method for citric acid production using agro-industrial residues (Prado, 2002). It offers potential advantages in the treatment and value addition of these residues (Brand et al., 2002). SSF is characterized by the development of microorganisms in a low-water activity environment on a non-soluble material acting both as nutrient source and physical support (Pandey et al., 2000; Soccol, 1994).
\end{abstract}

* Author for correspondence 
In recent years, a considerable interest has been shown in using agricultural products and their residues as alternative sources of carbon such for citric acid production by A. niger (Soccol, 2001; Kolicheski, 1995; Soccol et al., 1999; Vandenberghe et al., 2000c). A variety of agroindustrial residues and by-products have been investigated with SSF techniques for their potential to be used as substrates for citric acid production (Vandenberghe et al., 2000a). A cost reduction on citric acid production can be achieved by using less expensive substrates, such as apple pomace, carrot and orange waste, cassava bagasse, coffee husk, corncob, kiwifruit peel, mussel processing wastes, okara (soy residue), rice and wheat bran (Vandenberghe et al., 1999; Garg and Hang, 1995; Aravantinos-Zafiris et al., 1994; Khare et al., 1995; Hang and Woodams, 1998; Vandenberghe, 2000). These residues are very well adapted to solid-state cultures due to their cellulosic and starchy nature. There has been an increasing trend towards efficient utilization of these residues, besides being a form of reducing environmental concerns (Soccol and Vandenberghe, 2003).

Brazil is the second largest producer of cassava, contributing with 23 million tons/year ( $\mathrm{Lu}$ et al., 1997). Industries that produce starch from cassava root generate daily thousands of tons of cassava bagasse (CB), a solid residue generated in the starch extraction process during separation stage (Vandenberghe et al., 2000a; Pandey et al., 2000; Vandenberghe et al., 2000c). It is composed basically of fibers and residual starch that is not extractable. $\mathrm{CB}$ is disposed in the environment causing serious pollution problems due to its high organic material content and biodegradability (Pandey et al., 2000). Utilization of CB by microbial fermentation has been shown to be promising.

The aim of this work was to evaluate the relationship between citric acid production by SSF of cassava bagasse and the respiration of Aspergillus niger LPB 21. SSF was employed using an horizontal drum bioreactor (semi-pilot scale) that was coupled with a gas chromatography system to evaluate the release of $\mathrm{CO}_{2}$ and the $\mathrm{O}_{2}$ production.

\section{MATERIALS AND METHODS}

\section{Microorganism}

A strain of Aspergillus niger LPB 21 was grown on potato-dextrose-agar (PDA) medium. The slants were incubated at $28{ }^{\circ} \mathrm{C}$ for seven days and preserved at $4{ }^{\circ} \mathrm{C}$ for two months.

\section{Substrate and Its Thermal Treatment}

Cassava bagasse (CB) was obtained from Agroindustrial Paranaense de Polvilho Ltda. (Paranavaí - PR, Brazil). It was ground in a mill and was sieved to obtain fractions between 0.8 $2.0 \mathrm{~mm}$ particle size. Heat treatment was carried out in order to gelatinize the residual starch of CB, by adding $110 \mathrm{ml}$ distilled water for $100 \mathrm{~g}$ of dry CB. Samples were heated at $121^{\circ} \mathrm{C}$ for 20 minutes (Vandenberghe, 2000).

\section{Nutrients}

Treated CB was supplemented with a salt solution containing $(\mathrm{g} / \mathrm{l})$ : urea 2.93, $\mathrm{KH}_{2} \mathrm{PO}_{4} 1.86$ and $\mathrm{FeSO}_{4} \cdot 7 \mathrm{H}_{2} \mathrm{O} 0.0105$. The solution was sterilized at $121{ }^{\circ} \mathrm{C}$ for $15 \mathrm{~min}$. After cooling, methanol (4\% v/v) was added under sterile conditions.

\section{Inoculum Preparation}

Spores of A. niger were produced in $250 \mathrm{ml}$ Erlenmeyer flasks containing $40 \mathrm{ml}$ PDA medium at $28{ }^{\circ} \mathrm{C}$ for seven days. The spores were harvested by homogenization with a solution $0.01 \%$ of Tween 80 and glass beads. The obtained suspension containing about $10^{8}$ spores $/ \mathrm{ml}$ was stored at $4{ }^{\circ} \mathrm{C}$ for seven days.

\section{Solid-State Fermentation (SSF)}

SSF was conducted in horizontal drum bioreactor (semi-pilot scale) with $2 \mathrm{~kg}$ of dry substrate. Treated and inoculated substrate was placed inside the fermenter. As shown in Fig. 1, the horizontal drum bioreactor consisted of a shovel coupled to a motor axis that rotated with a controlled speed. Thus, material was revolved 3 to 4 times a day. After $20 \mathrm{~h}$ of fermentation, saturated air was inserted continually into drum $\left(360 \mathrm{dm}^{3} / \mathrm{h}\right)$ in order to control substrate temperature and moisture (Vandenberghe, 2000). Fermentation was carried out for $144 \mathrm{~h}$ at room temperature with initial substrate moisture of $60 \%$. 


\section{Kinetic Study of Citric Acid Production}

A kinetic study was carried out in order to verify the evolution of some important factors during fermentation. Every $24 \mathrm{~h}$, samples were collected for evaluation of citric acid production as well as the changes of $\mathrm{pH}$, protein, residual starch and reducing sugars. All determinations were conducted in triplicate.

\section{Estimation of Growth}

The respiratory metabolism of the microorganism was evaluated by determining the $\mathrm{O}_{2}$ consumption and $\mathrm{CO}_{2}$ production. This was utilized to estimate the biomass biosynthesis by the fungal culture.
The exhausted saturated air from the bioreactor was passed through silica gel column and then analyzed by gas chromatography in order to determine the oxygen uptake rate and the $\mathrm{CO}_{2}$ evolved during the process.

\section{Analytical Methods}

Citric acid extraction was carried out by mixing 5 $\mathrm{g}$ fermented sample with $50 \mathrm{ml}$ of distilled water on a magnetic stirrer for $10 \mathrm{~min}$ and filtering through filter paper. The filtrate obtained was subjected to high performance liquid chromatograph (HPLC) analysis using a Shimadzu LC-10AD.

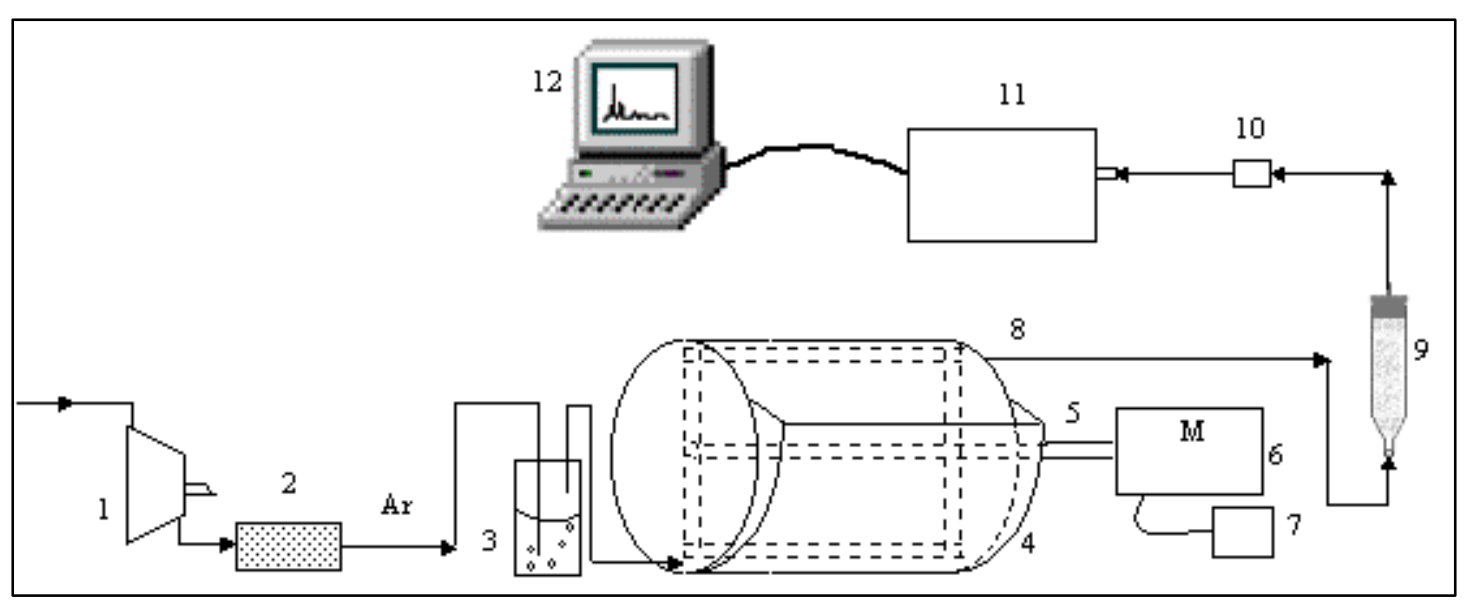

Figure 1 - Outline of the horizontal drum bioreactor and auxiliary equipments: (1) compressor, (2) air filter, (3) humidifier, (4) horizontal drum bioreactor, (5) axis, (6) motor, (7) speed controller, (8) air discharge, (9) silica gel column, (10) automatic injector, (11) gaseous chromatograph, (12) computer.

A temperature of $60{ }^{\circ} \mathrm{C}$ and $5 \mathrm{mM} \mathrm{H}_{2} \mathrm{SO}_{4}$ and the mobile phase at a flow-rate of $0.6 \mathrm{ml} / \mathrm{min}$ were used. Citric acid was detected in the column eluate by differential refractometer (Shimadzu RID-10A). Protein determination was carried out following Stutzer method (Vervack, 1973), reducing sugars by the Somogyi-Nelson method (Somogyi, 1945; Nelson, 1944) and residual starch through enzymatic method proposed by "National Starch Chemical Corporation" (1985). Biomass analytical determination was made subtracting the quantity of protein in a certain time of initial quantity of protein present in the substrate.

\section{RESULTS AND DISCUSSION}

One of the most important factors of SSF with filamentous fungus, both in laboratory and industrial scale is the estimation of biomass. Methods used in liquid fermentation cannot be applied in SSF. This fact is due to the intense adhesion of filamentous fungus mycelium to the solid substrate/support and to the SSF system heterogeneity. $\mathrm{O}_{2}$ consumption and $\mathrm{CO}_{2}$ production is the result of metabolic activity of microorganisms from which they obtain the necessary energy for growth and maintenance. Besides, the metabolic activity is associated to 
growth and it can be employed for biomass biosynthesis estimation (Raimbault et al., 1997).

Pintado et al. (1998) showed that an environment with high concentrations of $\mathrm{CO}_{2}$ has a positive effect on citric acid synthesis. In fact, low oxygen environment is directly involved with growth limitation, which is crucial for citric acid production. Low aeration rates are supposed to limit the respiration activity of A. niger and, consequently, to turn the metabolism to citric acid synthesis.

The study of citric acid production by A. niger in SSF revealed the importance of a $\mathrm{CO}_{2}$ rich atmosphere. The high partial pressure of $\mathrm{CO}_{2}$ probably retarded spores liberation of the filamentous fungus and favors citric acid synthesis (Vandenberghe, 2000). It is known that growth limitation is a very important factor in citric acid production. Consequently, it is possible to optimize citric acid accumulation by retarding the start of aeration. A different strategy of aeration, based on its retardation, was adopted for A. niger in order to control the metabolism of growth. Preliminary studies in columns (laboratory scale) showed that the start of air supply after $20 \mathrm{~h}$, the concentration of citric acid reached $309 \mathrm{~g} / \mathrm{kg}$ of dry cassava bagasse (DCB). However, when aeration started at $0 \mathrm{~h}$, the production was only $267.3 \mathrm{~g} / \mathrm{kg}$ DCB. The difference represented $13.5 \%$ (Vandenberghe, 2000). Thus, aeration in horizontal drum was started after $20 \mathrm{~h}$ of fermentation.

\section{Kinetics of Citric Acid Production by SSF in Horizontal Drum Bioreactor}

Citric acid production and other characteristic parameters, such as substrate consumption, $\mathrm{pH}$ evolution and biomass, were followed during SSF of $A$. niger with cassava bagasse. Fig. 2 presents the results obtained for SSF of CB in horizontal drum bioreactor. Maximal citric acid accumulation was reached in $144 \mathrm{~h}$ corresponding to $26.9 \mathrm{~g} / 100$ $\mathrm{g}$ of DCB. Starch consumption was $38.9 \mathrm{~g} / 100 \mathrm{~g}$ of DCB and the total yield was $69 \%$. These results were considered satisfactory. It is also important to point out other factors that could affect the metabolism of the fungus and citric acid production such as heat and oxygen transfer which are the main scale-up problems of SSF.

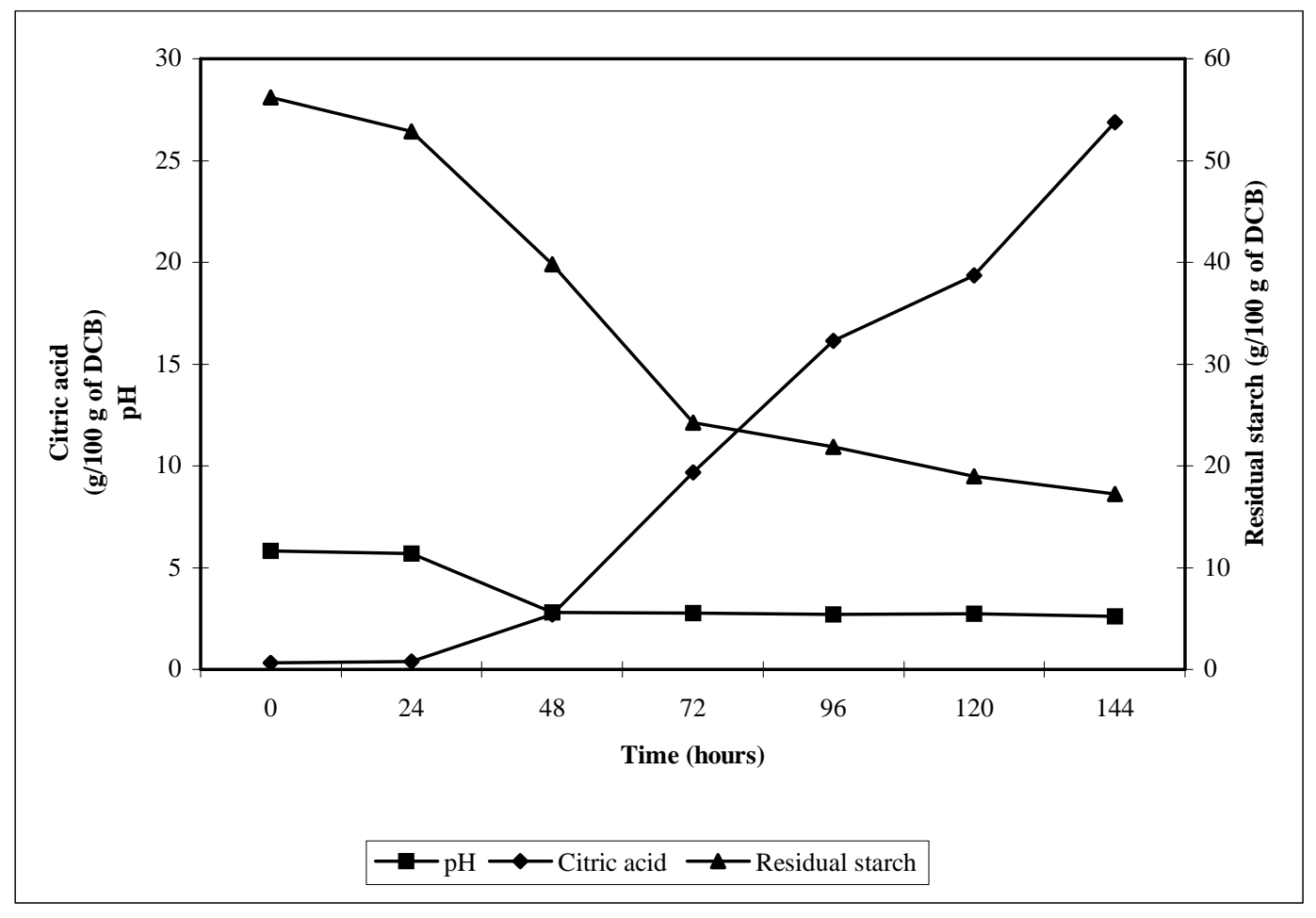

Figure 2 - Citric acid production, $\mathrm{pH}$ evolution and starch consumption during SSF of cassava bagasse by Aspergillus niger LPB 21 in horizontal drum bioreactor. 


\section{Respiratory Metabolism Analysis}

A mass balance was carried out for the estimation of oxygen uptake rate (OUR) and $\mathrm{CO}_{2}$ evolved in terms of volumetric flow $(\mathrm{L} / \mathrm{h})$. If exhausted airflow $\left(\mathrm{F}_{\text {out }}\right)$ is known and the inlet airflow is $\mathrm{F}_{\mathrm{in}}$, the following equations could be considered:

$$
\begin{gathered}
V_{\mathrm{O}_{2} \text { out }}=\left(\frac{\% O_{2 \text { out }}}{100}\right) \times F_{\text {out }} \\
V_{\mathrm{CO}_{2} \text { out }}=\left(\frac{\% C O_{2 \text { out }}}{100}\right) \times F_{\text {out }} \\
F_{\text {out }}=V_{\mathrm{O}_{2} \text { out }}+V_{\mathrm{CO}_{2} \text { out }}+V_{\mathrm{N}_{2} \text { out }} \\
V_{\mathrm{N}_{2} \text { out }}=\left(\frac{100-\% \mathrm{O}_{2 \text { out }}-\% \mathrm{CO}_{2 \text { out }}}{100}\right) \times F_{\text {out }}
\end{gathered}
$$

It is known that:

$$
\begin{gathered}
V_{N_{2} \text { in }}=\frac{79}{100} \times F_{\text {in }} \\
V_{N_{2} \text { in }}=V_{N_{2} \text { out }}
\end{gathered}
$$

Then, the equation (7) relates the inlet and the outlet airflow:

$$
F_{\text {in }}=\frac{\left(100-\% O_{2 o u t}-\% C O_{2 o u t}\right) \times F_{\text {out }}}{79}
$$

The mass balance for oxygen is given in order to evaluate the volumetric flow of uptake $\mathrm{O}_{2}$ :

$$
V_{O_{2} \text { uptake }}=\left(\frac{21}{100}\right) \times F_{\text {in }}-\left(\frac{\% O_{2 \text { out }}}{100}\right) \times F_{\text {out }}
$$

For the estimation of OUR and $\mathrm{CO}_{2}$ evolved in mass flow units $(\mathrm{mol} / \mathrm{h})$, it was considered that the air was an ideal gas at the respective volumetric flow ( $V_{\mathrm{O}_{2} \text { uptake }}$ and $V_{\mathrm{CO}_{2} \text { out }}$ ) and the proper corrections for temperature conditions.

Considering the balance of OUR, it was obtained the equation 9 (Pandey et al., 2001).

$$
\begin{aligned}
X_{n}= & \left\langle Y_{X / O} \Delta t\right. \\
& \left\{\frac{1}{2}\left[\left(\frac{d O_{2}}{d t}\right)_{t=0}+\left(\frac{d O_{2}}{d t}\right)_{t=n}\right]+\sum_{i=1}^{i=n-1}\left(\frac{d O_{2}}{d t}\right)_{t=i}\right\} \\
& \left.+\left(1-\frac{a}{2}\right) X_{0}-a \sum_{i=1}^{i=n-1} X_{i}\right\rangle /\left(1+\frac{a}{2}\right)
\end{aligned}
$$

where:

$$
a=m_{X} Y_{X / O} \Delta t
$$

From the results of the OUR and $\mathrm{CO}_{2}$ production, some bioprocess parameters were estimated. The estimation of biomass at a certain time $\left(X_{n}\right)$ consisted of assuming values for its yield based on oxygen consumption $\left(\mathrm{Y}_{\mathrm{X} / \mathrm{O}}\right)$ and biomass maintenance coefficient $\left(\mathrm{m}_{\mathrm{X}}\right)$. FERSOL software (Rodriguez-Leòn et al., 1988) was used in the calculations. Seven points of biomass were considered and analytically determined at 0, 24, 48, 72, 96, 120 and $144 \mathrm{~h}$ of fermentation. The software allowed the determination of the equation coefficients by successive approach. From the values of OUR and $\mathrm{CO}_{2}$ production, obtained experimentally, the system determined a biomass yield $\left(\mathrm{Y}_{\mathrm{X} / \mathrm{O}}\right)$ of $4.372 \mathrm{~g}$ of biomass/g of consumed $\mathrm{O}_{2}$ and a biomass maintenance coefficient $\left(\mathrm{m}_{\mathrm{X}}\right)$ of $0.0162 \mathrm{~g}$ of consumed $\mathrm{O}_{2} /(\mathrm{g}$ of biomass.h).

Fig. 3 presents the evolution of $\mathrm{O}_{2}$ and $\mathrm{CO}_{2}$ percentages during fermentation such as estimated biomass and analytical determined biomass. The production of $\mathrm{CO}_{2}$ did not exceed $0.4 \%$. These results showed that the limitation of growth was excessive and probably the strategy of retarding aeration in $20 \mathrm{~h}$ was not favorable to this system. This was also showed by the value of biomass production during fermentation, which was only $0.87 \mathrm{~g} / 100 \mathrm{~g}$ of DCB.

After $50 \mathrm{~h}$ of fermentation $\mathrm{CO}_{2}$ production reached its maximum. At this point, citric acid production was about $3 \mathrm{~g} / 100 \mathrm{~g}$ of DCB. These facts showed that the microorganism gave preference to citric acid production and not to biomass formation. The difference between estimated and analytical determined biomass, mainly after $72 \mathrm{~h}$ of fermentation, was an indicative that indirect method of biomass determination through on-line monitoring of $\mathrm{CO}_{2}$ production could probably correct the errors presented in biomass determination by analytical methods.

This work showed the feasibility of using A. niger LPB 21 in SSF of cassava bagasse for citric acid 
production. From evolution of kinetic parameters of fermentation, such as $\mathrm{CO}_{2}$ production and $\mathrm{O}_{2}$ uptake, it was observed that low respiration rates favoured the production of high concentrations of citric acid. On-line monitoring of fermentation allowed the determination of the relationship between $\mathrm{CO}_{2}$ evolution, biomass and citric acid production by Aspergillus niger.

Citric acid production in horizontal drum bioreactor (semi-pilot scale) reached $26.9 \mathrm{~g} / 100 \mathrm{~g}$ DCB corresponding to a yield of $69 \%$ based on starch consumption. In this case, growth was limited excessively and there was not enough biomass to produce higher levels of citric acid. Besides, other operational factors, such as temperature control, probably affected the fungus growth and citric acid synthesis.

It is very important to understand how all process parameters act on fungus metabolism and the synthesis of some metabolites. When working at larger scales, a large number of factors can affect process behavior such as oxygen and heat transfer, particle size, layer, type and shape of bioreactor. Consequently, a detailed scale-up study must be conducted in order to test every factor and their influence on a specific process.

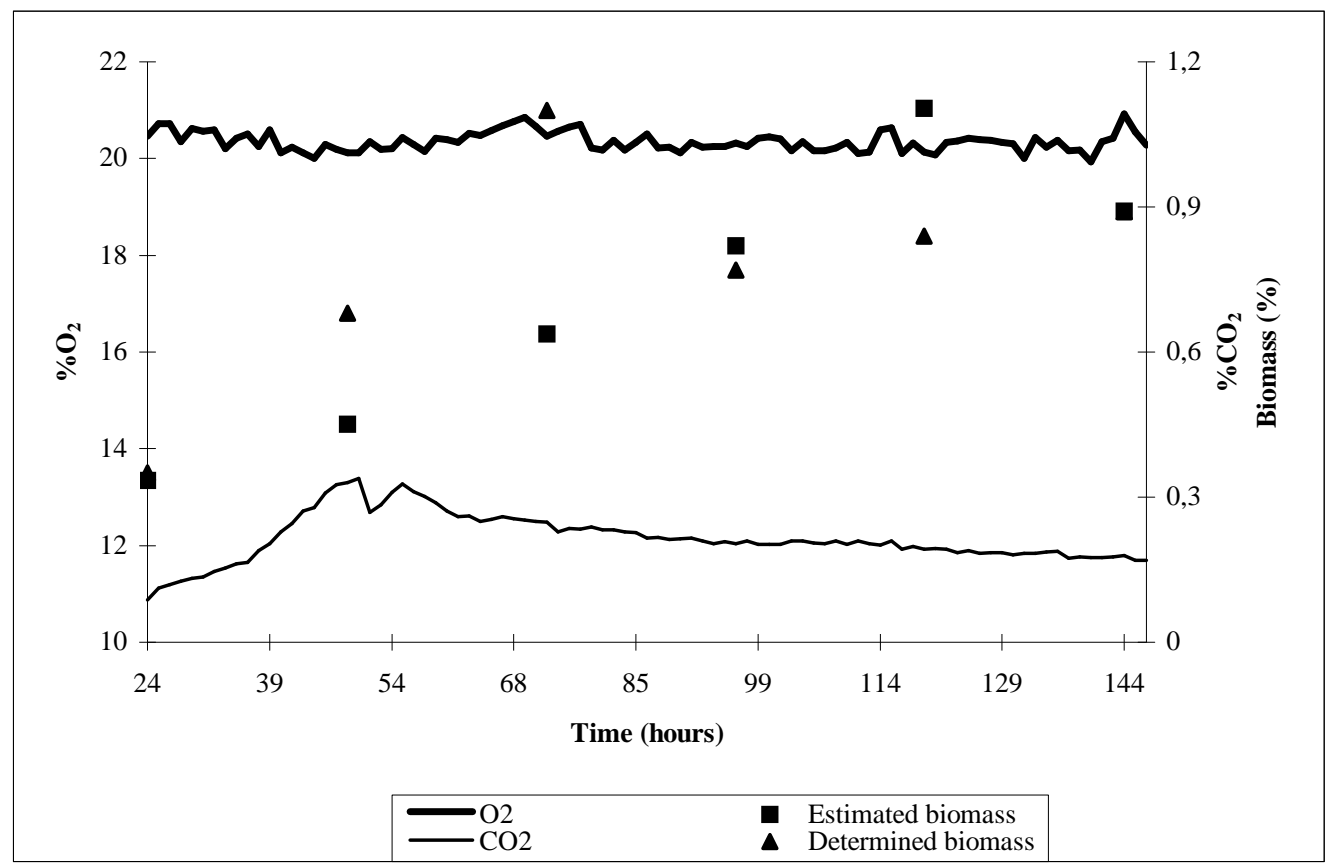

Figure 3 - Evolution of kinetic parameters of citric acid production by SSF of cassava bagasse by Aspergillus niger LPB 21 in horizontal drum bioreactor.

\section{ACKNOWLEDGEMENTS}

Flávera Camargo Prado and Carlos Ricardo Soccol thank CAPES and CNPq, respectively for financial support, latter for a scholarship under the conditions of a Scientific Productivity Scheme.

\section{RESUMO}

Este estudo permitiu verificar a relação ente a produção de ácido cítrico e a respiração do Aspergillus niger LPB 21 na fermentação no estado sólido do bagaço de mandioca. Os experimentos foram realizados em biorreator tipo tambor horizontal acoplado com um sistema de cromatografia gasosa. A fermentação foi conduzida durante $144 \mathrm{~h}$ com $60 \%$ de umidade inicial do substrato usando bagaço de mandioca termicamente tratado como única fonte de carbono. $\mathrm{O}$ ar de saída do biorreator foi analisado para monitorar a produção de $\mathrm{CO}_{2}$ e o consumo de $\mathrm{O}_{2}$ com o objetivo de estimar a biomassa sintetizada pelo fungo. A atividade metabólica do crescimento do Aspergillus niger está associada à produção de ácido cítrico. Usando o software FERSOL, o sistema determinou uma biomassa de $4.372 \mathrm{~g}$ de biomassa/g de $\mathrm{O}_{2}$ consumido. Os 
valores da biomassa estimada e da determinada analiticamente seguiram a mesma tendência mostrando que o modelo matemático aplicado foi adaptado.

\section{REFERENCES}

Aravantinos-Zafiris, G.; Tzia, C.; Oreopoulou, V. and Thomopoulos, C. D. (1994), Fermentation of orange processing wastes for citric acid production. J. Sci. Food Agric., 65, 117-120.

Brand, D.; Pandey, A.; Rodriguez-León, J. A.; Roussos, S.; Brand, I. and Soccol, C. R. (2002), Relation Between coffee husk caffeine degradation and respiration of Aspergillus sp. in solid state fermentation. Appl. Biochem. Biotech., 102, 169-178.

Garg, N. and Hang, Y. D. (1995), Microbial production of organic acids from carrot processing waste. J. Food Sci. Technol., 32, 119-121.

Hang, Y. D. and Woodams, E. E. (1998), Production of citric acid from corncobs by Aspergillus niger. Biores. Technol., 65, 251-253.

Khare, S. K.; Jha, K. and Gandhi, A. P. (1995), Short Comunication: Citric acid production from okara (soy-residue) by solid-state fermentation. Biores. Technol., 54, 323-325.

Kolicheski, M. B. (1995), Produção de Ácido Cítrico por Fermentação no Estado Sólido utilizando como substrato Bagaço de Mandioca. MSc Thesis, Universidade Federal do Paraná, Brazil.

Lu, M.; Brooks, J. D. and Maddox, I. S. (1997), Citric acid production by solid-state fermentation in a packed-bed reactor using Aspergillus niger. Enz. Microbial Technol., 21, 392-397.

NATIONAL STARCH CHEMICAL CORPORATION. (1985), NS -00396/85

Nelson, N. (1944), A photometric adaptation of the Somogyi method for the determination of glucose. $J$. Biol. Chem., 153, 375-380.

Pandey, A.; Soccol, C. R.; Nigam, P.; Soccol, V. T. and MOHAN R. (2000), Biotechnological potential of agro-industrial residues. II. Cassava bagasse. Biores. Technol. 74, 81-87.

Pandey, A.; Soccol, C. R.; Rodriguez-León, J. A. and Nigam, P. (2001), Production of organic acids by solid-state fermentation. In: Solid-state fermentation in biotechnology -fundamentals and applications. New Delhi : Asiatech Publishers. pp. 113-126.

Pintado, J.; Torrado, A.; González, M. P. and Murado, M. A. (1998), Optimization of nutrient concentration for citric acid production by solid -state culture of Aspergillus niger on polyurethane foams. Enz. Microbial Technol., 23, 149-156.

Prado, F. C. (2002), Desenvolvimento de Bioprocesso em escala semipiloto para produção de ácido cítrico por fermentação no estado sólido a partir do bagaço de mandioca. MSc Thesis, Universidade Federal do Paraná, Brazil.

Raimbault, M.; Roussos, S. and Lonsane, B. K. (1997), Solid state fermentation at ORSTOM: History, evolution and perspectives. In: Advances in solid substrate fermentation. Kluwer Acad Pub. pp. 577-612.

Rodriguez-León, J. A.; Sastre, L.; Echevarria, J.; Delgado, G. and Bechstedt, W. (1988), A mathematical approach for the estimation of biomass production rate in solid state fermentation. Acta Biotechnol., 8, 307-310.

Soccol, C. R. (2001), Developpement de bioprocedes pour la valorization post-recolt de produits et sous produits agricoles tropicaux. Memoire (Présente en vue de l'Habilitation à Diriger des Rcherches). Université de Provence. Marseille.

Soccol, C. R.; Prado, F. C.; Vandenberghe, L. P. S. and Pandey, A. (2003), General aspects in citric acid production by submerged and solid-state fermentation. In: Concise Encyclopedia of Bioresource Technology. New York : The Haworth Press. pp. 652-664.

Soccol, C. R. and Vandenberghe, L. P. S. (2003), Overview of solid-state fermentation in Brazil. Biochem. Eng. J., 13, 205-219.

Soccol, C. R.; Vandenberghe, L. P. S. and Lebeault, J. M. (1999), Processo de produção de ácido cítrico por fermentação no estado sólido utilizando o fungo Aspergillus niger. Pt. Br. DEINPI/PR 00175.

Soccol, C. R. (1994), Contribuição ao estudo da fermentação no estado sólido em relação com a produção de ácido fumárico, biotransformação de resíduo sólido de mandioca por Rhizopus e Basidiomacromicetos do gênero Pleurotus. Thesis (Prof. Titular) - Universidade Federal do Paraná. Curitiba - PR, Brazil.

Somogyi, M. (1945), A new reagent for the determination of sugars. J. Biol. Chem., 160, 61-68.

Vandenberghe, L. P. S.; Soccol, C. R.; Pandey, A. and Lebeault, J. M. (2000a), Cassava bagasse, an alternative substrate for citric acid production in solid-state fermentation. In: International Biotechnology Symposium and Exhibition, 11., 3-8 Sep. Berlin. Proceedings... Book of Abstracts. Frankfurt : Dechema, 4, 153-155.

Vandenberghe, L. P. S.; Soccol, C. R.; Pandey, A. and Lebeault, J. M. (2000b), On-line monitoring of citric acid production using respirometry in solid state fermentation with cassava bagasse. In: International Symposium on the Bioconversion of Renewable Raw Materials, Hannover. Proceedings... Abstracts More quality of life by means of biotechnology.

Vandenberghe, L. P. S.; Soccol, C. R.; Pandey, A. and Lebeault, J. M. (2000c), Solid-state fermentation for the synthesis of citric acid by Aspergillus niger. Biores. Technol., 74, 175-178. 
Vandenberghe, L. P. S.; Soccol, C. R.; Pandey, A. and Lebeault, J. M. (1999), Review: Microbial production of citric acid. Braz. Arch. Biol. Techn., 42, 263-276.

Vandenberghe, L. P. S. (2000), Développement d'un procédé pour la production d'acide citrique par fermentation en milieu solide à partir de résidus de l'agro-industrie du manioc. Thesis (Doctorate). Universite de Technologie de Compiegne. Compiegne.

Vervack, W. (1973), Analyse des alimentes, méthods courantes d'analyses. Louvain-la-Neuve : Laboratoire de Biochimie de la Nutrition.

Received: September 29, 2004; Revised: February 25, 2005; Accepted: March 25, 2005. 